\title{
Reducing gut effects from Cryptosporidium parvum infection in dairy calves through prophylactic glucagon-like peptide 2 therapy or feeding of an artificial sweetener
}

\author{
E. E. Connor, ${ }^{\star 1}$ E. H. Wall,† D. M. Bravo,† C. M. Evock-Clover, ${ }^{\star}$ T. H. Elsasser, $\ddagger$ R. L. Baldwin VI, ${ }^{\star}$ M. Santín, $\S$ \\ B. T. Vinyard,\# S. Kahl, $\ddagger$ and M. P. Walker* \\ *Animal Genomics and Improvement Laboratory, USDA-Agricultural Research Service, Beltsville, MD 20705 \\ †Pancosma SA, Geneva CH-1218, Switzerland \\ $\ddagger$ Animal Biosciences and Biotechnology Laboratory, \\ §Environmental Microbial and Food Safety Laboratory, and \\ \#Northeast Area, Statistics Group, USDA-Agricultural Research Service, Beltsville, MD 20705
}

\begin{abstract}
Glucagon-like peptide 2 (GLP-2) therapy was shown previously to reduce inflammation-related gut damage from coccidiosis in dairy calves, and feeding of artificial sweetener stimulates GLP-2 secretion from intestinal $\mathrm{L}$ cells. The purpose of this study was to determine whether GLP-2 treatment or artificial sweetener feeding beginning 1 wk before an experimental inoculation with the coccidian parasite Cryptosporidium parvum can reduce infection-related intestinal damage in Holstein bull calves. Newborn calves were assigned to 1 of 4 treatment groups of 6 calves each, including noninfected control calves injected s.c. every $12 \mathrm{~h}$ with control buffer $(\mathrm{CON})$, infected control calves injected s.c. every $12 \mathrm{~h}$ with control buffer (INF), infected calves injected s.c. every $12 \mathrm{~h}$ with $50 \mu \mathrm{g} / \mathrm{kg}$ of body weight of GLP-2 (GLP2), and infected calves injected s.c. every $12 \mathrm{~h}$ with control buffer and supplemented in the diet with Sucram (Pancosma, Geneva, Switzerland) at $400 \mathrm{mg} /$ $\mathrm{kg}$ of dry matter of milk replacer (SUC). Treatments were initiated on d 1, and calves in INF, GLP2, and SUC were orally dosed on d 8 with 12,500 C. parvum oocysts. Fecal scores were recorded daily, plasma was collected on d 1, 8, 12, 15, and 18 to evaluate markers of inflammation, and fecal samples were collected on d 1,8 , and every other day thereafter to determine the presence of oocysts. Calves were euthanized on d 18 for collection of intestinal tissues and histological and gene expression analyses. Relative to CON, calves in INF exhibited an increase in diarrhea severity, increased plasma serum amyloid A concentration on d 15 and 18, reduced intestinal villus height, increased villus apoptosis and crypt cell proliferation, and increased intestinal
\end{abstract}

Received August 11, 2016.

Accepted December 8, 2016.

${ }^{1}$ Corresponding author: erin.connor@ars.usda.gov
mRNA expression of MARVELD2 and GPX2. However, calves in SUC and GLP2 had reduced diarrhea severity and fecal C. parvum oocyst shedding, reduced plasma serum amyloid A concentration on d 15 and 18, and, depending on the intestinal segment, increased villus height, reduced crypt cell proliferation, and reduced mRNA expression of MARVELD2, GPX2, and other tight junction proteins relative to INF. Lastly, GLP2 and SUC exhibited increased intestinal mass-to-length ratio and decreased length-to-empty body weight ratio relative to INF. Our findings suggest that GLP-2 and Sucram treatments administered before a low-level $C$. parvum exposure may contribute to fewer effects on intestinal integrity, morphology, and inflammation in response to infection, and shorter, denser intestines.

Key words: coccidiosis, dairy calf, glucagon-like peptide 2, gut health

\section{INTRODUCTION}

Over $50 \%$ of early-life calf mortality is due to diarrhea (scours), and Cryptosporidium parvum is among the primary causative factors of this disease (Cho and Yoon, 2014). Diarrhea also contributes to calf morbidity, nutrient malabsorption, and poor production performance (Lorenz et al., 2011). Depending on the cause and severity of disease, treatment of diarrhea often is focused on palliative care, including replacement of lost fluids and electrolytes, reestablishment of acid-base balance within the digestive tract, and may include administration of anti-inflammatory drugs or antibiotics (Kahn and Line, 2010). In the case of cryptosporidiosis, halofuginone lactate is the only licensed drug available for prevention and treatment of the disease in newborn calves, which has shown limited benefits on reducing infection or animal production (Jarvie et al., 2005; De Waele et al., 2010) and is not licensed for use in the United States. Thus, therapies that minimize the nega- 
tive effects of diarrhea on gut function and improve animal productivity could greatly benefit the profitability of dairy calf production and improve animal well-being.

Recent studies in dairy calves suggest glucagon-like peptide 2 (GLP-2) therapy may be beneficial in the treatment of calf scours to reduce intestinal damage, improve barrier function, and increase nutrient absorption based on its various effects on the intestinal mucosa and blood flow (Taylor-Edwards, et al., 2011; Connor et al., 2013; Walker et al., 2015). Furthermore, artificial sweeteners can stimulate natural GLP-2 release from ruminant intestine, which is believed to be through the activation of sweet taste receptors expressed on intestinal L cells (Moran et al., 2014). Therefore, the potential exists to use dietary sweeteners to promote GLP-2-mediated benefits on intestinal health and function and reduce the negative effects of calf scours on dairy production. The purpose of the current study was to determine whether GLP-2 treatment or feeding of artificial sweetener to newborn dairy calves beginning 1 wk before oral inoculation with C. parvum oocysts can reduce the severity of diarrhea and negative effects of cryptosporidiosis on the gut, including changes in intestinal villus height, crypt cell proliferation, cellular apoptosis, indicators of inflammation and barrier function, and nitro-oxidative stress.

\section{MATERIALS AND METHODS}

All procedures involving animals were approved by the Beltsville Area Animal Care and Use Committee protocol number 14-001.

\section{Animals}

Holstein bull calves $(\mathrm{n}=24 ; 6 /$ treatment $)$ were purchased from a local commercial dairy farm or obtained from the Beltsville Agricultural Research Center (BARC) dairy herd. Calves were fed colostrum at their first feeding and were transported at 1 to $2 \mathrm{~d}$ of age to an environmentally controlled building on the BARC research campus. All calves were housed in individual concrete pens $\left(7.3 \mathrm{~m}^{2}\right)$ bedded with wood shavings. Calves received 750,000 IU of penicillin G benzathine and penicillin $\mathrm{G}$ procaine, $2.5 \mathrm{~mL}$ of BO-SE (Merck Animal Health, Summit, NJ), $750 \mathrm{mg}$ of vitamin C, 100,000 IU of vitamin A, 10,000 IU of vitamin D, $200 \mathrm{mg}$ of iron dextran, and $35 \mathrm{~mL}$ of Quatracon- $2 \times$ (antiserum to provide passive immunity to Arcanobacterium pyogenes, Escherichia coli, Pasteurella multocida, and Salmonella typhimurium; Boehringer Ingelheim Vetmedica Inc., St. Joseph, MO) at arrival and were confirmed negative for bovine viral diarrhea by a PCR-based blood test conducted by the Cornell University Animal Health Di- agnostic Center (Ithaca, NY). All calves were provided continuous access to water and were fed a commercial milk replacer (Premium 20/20 Biomos, nonmedicated; Strauss Feeds, LLC, Watertown, WI) according to BW at a rate of $84 \mathrm{~mL} / \mathrm{kg}$ daily, divided equally between 2 meals fed at approximately 0700 and $1300 \mathrm{~h}$. The milk replacer contained $20.0 \% \mathrm{CP}, 20.0 \%$ crude fat, $0.15 \%$ crude fiber, 0.75 to $1.25 \% \mathrm{Ca}, 0.70 \% \mathrm{P}, 66,000 \mathrm{IU} / \mathrm{kg}$ of vitamin $\mathrm{A}, 22,000 \mathrm{IU} / \mathrm{kg}$ vitamin $\mathrm{D}_{3}$, and $440 \mathrm{IU} /$ $\mathrm{kg}$ vitamin E. On d 1, 8, 12, 15, and 18, calves were weighed before feeding and the volume of milk replacer fed was adjusted at the next (afternoon) feeding. On $\mathrm{d}$ 1 , mean $( \pm \mathrm{SD})$ calf age was $8( \pm 2) \mathrm{d}$ and $\mathrm{BW}$ was 44 $( \pm 6) \mathrm{kg}$.

\section{Experimental Design}

The experiment was conducted in 4 blocks: the first block consisting of noninfected control calves injected with buffer $(\mathbf{C O N} ; \mathrm{n}=6)$, and the remaining 3 blocks consisting of 6 calves each assigned by age and $\mathrm{BW}$ to 1 of 3 treatment groups $(\mathrm{n}=2$ per treatment group in each of 3 blocks) and experimentally infected with C. parvum. The 3 groups of infected calves were (1) injected with buffer (INF; $\mathrm{n}=6$ ); (2) injected with buffer and supplemented with Sucram (Pancosma, Geneva, Switzerland) at $400 \mathrm{mg} / \mathrm{kg}$ of DM of milk replacer (SUC; $\mathrm{n}=6)$ as recommended by the manufacturer; and (3) injected with GLP-2 (GLP2; n =6).

\section{Plasma Analyses}

On d 1, 8, 12, 15, and 18, blood was collected from each calf before feeding by jugular venipuncture using a heparinized Vacutainer tube (Becton Dickinson, Franklin Lakes, NJ). Plasma was harvested from whole blood after centrifugation $\left(1,932 \times g, 20 \mathrm{~min}, 4^{\circ} \mathrm{C}\right)$ and stored at $-20^{\circ} \mathrm{C}$. Serum amyloid A (SAA) was measured in duplicate samples using a multispecies SAA ELISA kit (Cat. No. TP-802; Tridelta Development Limited, Maynooth, County Kildare, Ireland) according to manufacturer's instructions. Intra- and interassay coefficients of variation for SAA were 4.6 and $10.0 \%$, respectively. Fatty acid binding protein 2 (FABP-2) was measured in duplicate samples using the Bovine FABP2, Intestinal ELISA Kit (Cat. No. E11F0030; Blue Gene, Shanghai, China) according to manufacturer's instructions. Intra- and interassay coefficients of variation for FABP-2 were 4.8 and $7.1 \%$, respectively. Plasma tumor necrosis factor $\alpha$ (TNF- $\alpha$ ) was measured in duplicate $250-\mu \mathrm{L}$ samples by RIA according to Kenison et al. (1990) using rabbit anti-bovine (recombinant) TNF- $\alpha$ antibody (Kingfisher Biotech, Saint Paul, MN) at a 1:160,000 final dilution. Intra-assay coefficient of variation was 
$12.1 \%$, minimum assay detection was $28 \mathrm{pg} / \mathrm{mL}$, and the linearity $\left(\mathrm{R}^{2}\right)$ of the standard curve was 0.97 .

\section{GLP-2 Treatment}

On d 1 through 18, calves in the GLP2 group received subcutaneous injections of bovine GLP-2 (AA 1 to 33 of the native bovine sequence, $95 \%$ purity; AAPPTec, LLC, Louisville, KY) every $12 \mathrm{~h}$ at a dosage of $50 \mu \mathrm{g} / \mathrm{kg}$ of BW (i.e., $100 \mu \mathrm{g} / \mathrm{kg}$ of BW daily) in sterile-filtered $0.01 M$ sodium carbonate/bicarbonate ( $\mathrm{pH} 8.5$ ) buffer. This dosage was shown to have beneficial effects on gut development and health in cattle (Taylor-Edwards et al., 2011; Connor et al., 2013; Walker et al., 2015). During the same period, calves in the CON, INF, and SUC groups received subcutaneous injections every 12 $\mathrm{h}$ with equivalent volumes of $0.01 \mathrm{M}$ sodium carbonate/bicarbonate ( $\mathrm{pH} 8.5$ ) buffer. The volume of GLP-2 administered was adjusted according to BW measured on d $1,8,12$, and 15 .

\section{C. parvum Inoculation and Fecal Analyses}

Fecal samples were collected by digital rectal stimulation from all calves at arrival to the BARC campus and on experimental d 1, 8, 10, 12, 14, 16, and 18. Feces were smeared directly onto glass microscope slides and examined for Cryptosporidium oocysts by immunofluorescence microscopy using MeriFluor Cryptosporidium/ Giardia reagents (Meridian Bioscience Inc., Cincinnati, $\mathrm{OH})$. The slide was covered with a coverslip and the entire well area was examined by fluorescence microscopy at $400 \times$ using a Zeiss Axioskop equipped with epifluorescence and a FITC-Texas Red dual-wavelength filter (Carl Zeiss Microscopy, LLC, Thornwood, NY). Calves in the INF, SUC, and GLP2 groups were orally infected with 12,500 C. parvum oocysts [Iowa isolate (Harley Moon) passaged through calves; Waterborne Inc., New Orleans, LA) on d 8 (i.e., 1 wk after treatments began) by spiking the milk replacer fed through a nippled bottle at the afternoon feeding period. As points of reference, $C$. parvum oocyst shedding in feces was reported as high as 132,000 eggs/g among Canadian beef calves sampled up to $70 \mathrm{~d}$ of age (McAllister et al., 2005), yet the $\mathrm{ID}_{50}$ (infectious dose $50 \%$ ) is only 20 oocysts for symptoms of diarrhea and fecal parasite shedding in newborn dairy calves maintained in an experimental (clean) environment (Zambriski et al., 2013). Fecal scores were recorded daily for each calf, where $1=$ normal; $2=$ stool not formed; $3=$ stool loose and runny; $4=$ stool watery with visible solids; and $5=$ stool watery with no visible solids, or bloody. Diarrhea severity index (DSI) was calculated for each calf as the sum of its daily fecal scores beginning the day of inoculation through the day of euthanasia; thus, a normal score of 1 every day would equate to a DSI of 11. At slaughter, fecal samples of $C$. parvum-infected calves from experimental block 4 ( $\mathrm{n}=2$ /treatment) were processed and oocysts quantified as described by Santín et al. (2004).

\section{Tissue Collection and RNA Extraction}

On d 18, calves were administered a bolus intravenous injection of 5-bromo-2'-deoxyuridine (BrdU; MP Biomedicals LLC, Santa Ana, CA; $20 \mathrm{mg} / \mathrm{mL}$ in $0.9 \%$ sterile saline, $\mathrm{pH} 8.2$ ) at a dosage of $5 \mathrm{mg} / \mathrm{kg}$ of BW through the jugular vein $2 \mathrm{~h}$ before slaughter to monitor proliferating intestinal cells. Calves were stunned by a penetrating captive bolt followed by exsanguination. The complete digestive tract was removed and processed as described by Connor et al. (2013). In addition, the epithelial mucosal layer was collected from segments of jejunum and ileum by scraping with a glass slide, stabilized in RNAlater (Life Technologies, Grand Island, NY) according to the manufacturer's instructions, and stored at $-80^{\circ} \mathrm{C}$ until RNA extraction. Tissues were homogenized in Qiazol Lysis Reagent (Qiagen, Valencia, CA) and total RNA was extracted using the RNeasy Mini Kit (Qiagen) with on-column DNase digestion. The 2100 Bioanalyzer with RNA 6000 Nano LabChip Kits (Agilent Technologies, Palo Alto, CA) was used to evaluate RNA quality, and RNA concentration was measured using a ND-1000 spectrophotometer (NanoDrop Technologies, Rockland, DE). The RNA integrity number of all RNA samples was at least 7.4, with the exception of a single sample from jejunum with a value of 6.6 .

\section{Morphometry and Immunostaining of Jejunum and Ileum}

Mean villus height was calculated using captured images of hematoxylin-and-eosin-stained tissue sections of well-oriented villi using a BX-40 microscope equipped with a DP-70 digital CCD camera (Olympus America Inc., Center Valley, PA). An average $( \pm \mathrm{SD})$ of $11( \pm 2)$ villi per calf was measured in jejunum and $13( \pm 2)$ villi were measured in ileum using Image-Pro software (Media Cybernetics Inc., Rockville, MD).

To estimate the number of apoptotic cells in ileum and jejunum, immunolabeling of fragmented DNA formed during the process of apoptosis was performed on formalin-fixed, paraffin-embedded sections by Histoserv Inc. (Germantown, MD) using terminal deoxynucleotidyl transferase end-labeling with digoxigeninconjugated deoxyuridine triphosphate (TUNEL assay). Labeled and unlabeled cells were manually counted 
from captured images (as described above using an Olympus BX-40 microscope fitted with a DP-70 digital CCD camera) of 10 villi and 10 crypts per calf, and the percentage of labeled cells in each intestinal segment was calculated. In ileum, an average $( \pm \mathrm{SD})$ of $256( \pm 73)$ cells/crypt and $276( \pm 121)$ cells/villus were counted. In jejunum, $240( \pm 76)$ cells/crypt and 278 $( \pm 127)$ cells/villus were counted. Due to quality and orientation of histological sections from jejunum, only 11 samples (3 CON, 3 INF, 3 GLP2, and 2 SUC) were suitable for cell counting from the TUNEL assay. Cell proliferation in intestinal crypts was assessed by BrdU staining as described by Connor et al. (2013). For each calf, the numbers of BrdU-labeled and -unlabeled cells were manually counted from captured images obtained as described above of 9 to 13 well-oriented crypts, and the percentage of BrdU-labeled cells was calculated. In jejunum, $547( \pm 194)$ cells/crypt were counted, and in ileum, $449( \pm 125)$ cells/crypt were counted. All counts were made by a single observer blinded to experimental treatment.

The presence and abundance of nitrated intestinal proteins in ileal mucosa was estimated as an indicator of inflammation-related nitro-oxidative stress using quantitative immunohistochemical procedures for 3'-nitrotyrosine (NT) previously described and validated for similar applications (Elsasser et al., 2007; Connor et al., 2013), with minor modifications described herein. Paraffin-embedded tissue sections on glass slides were deparaffinized by traditional immersion in a triplicate series each of xylene then absolute ethanol baths. Slides were transferred to a solution of methanol containing $3 \% \mathrm{H}_{2} \mathrm{O}_{2}$ for 30 min and then rehydrated into aqueous Tris-saline buffer ( $\mathrm{pH} 7.5)$ through a series of 5 baths decreasing in ethanol concentration $(100,100,95$, and $70 \%$, then distilled water). Tissues were treated for 10 min with 0.1\% Triton-X-100 (Sigma-Aldrich, St. Louis, MO) and rewashed in Tris-saline buffer. Nonspecific blocking was accomplished by incubating the slides for $1 \mathrm{~h}$ at $24^{\circ} \mathrm{C}$ in Tris-saline containing $3.5 \%$ normal goat serum (Sigma Biologicals, St. Louis, MO). Slides were further incubated overnight with rabbit anti-NT primary antibody (1:300, Life Technologies, Eugene, OR) at $4^{\circ} \mathrm{C}$. After 3 washes with Tris-saline buffer, secondary antibody (goat anti-rabbit IgG, Abcam Laboratories, Cambridge, MA) was applied for $2 \mathrm{~h}$ at room temperature. Following rinsing, all slides were incubated simultaneously by immersion into $200 \mathrm{~mL}$ of Tris buffer $(\mathrm{pH}$ 7.5) containing $150 \mathrm{mg}$ of 3,3'-diaminobenzidine $\mathrm{HCl}$ and $50 \mu \mathrm{L} 30 \% \mathrm{H}_{2} \mathrm{O}_{2}$. A slide containing intestinal tissue known to be positive for NT immunostaining from Connor et al. (2013) was processed along with the present experiment slides and the 3,3'-diaminobenzidine $\mathrm{HCl}$ color development monitored with the development of the brown staining in the correct locations of the positive control. Staining development was quenched by immersion into ice-cold Tris buffer followed by nuclear counterstaining for $1 \mathrm{~min}$ with Carazzi's hematoxylin (Bancroft and Stevens, 1982), dehydration through ethanol to xylene, and finished with the addition of glass coverslips. For quantitating cellular NT content as a valid marker for the presence of nitro-oxidative stress across treatments, 5 separate images of each animal's intestinal tissue were captured using an Olympus DP-70 CCD camera mounted on an Olympus BX-40 microscope. In addition, 1 image of a slide containing the known NT-positive control was captured. For each animal, a master composite of the 5 images for that animal plus the 1 image of the positive control was formed. The NT staining for the NT-positive control was used to establish the *.RBG pixel identification algorithm used by the analysis program (Image-Pro Premier Ver. 9.1, Media Cybernetics). For each master image and to maximize continuity across the master images, the total pixels per cell of the positive control was adjusted to differ among all master images by less than $1 \%$. With that optimization established, the positive pixel identification criteria were applied to each of the other 5 images of the master and the analytical data captured as associated with areas of interest particular to the villi. Data consisted of percentage of positive cells, mean number of positive pixels per cell, and pixel cluster size (area) for positive cells.

\section{Quantitative Real-Time PCR}

The mRNA expression of the pathogen recognition protein toll-like receptor 2 (TLR2), proinflammatory cytokines interleukin 18 (IL18) and tumor necrosis factor $\alpha(T N F)$, the antioxidant enzyme glutathione peroxidase 2 (GPX-2), the cellular tight junction proteins tricellulin (MARVELD2), occludin (OCLN), and tight junction protein 1 (TJP1), and the secretory protein trefoil factor 3 (TFF3) was quantified in jejunum and ileum epithelium using the CFX96 Touch qPCR System (Bio-Rad Laboratories, Hercules, CA). Reverse transcription using $1.0 \mu \mathrm{g}$ of total RNA per $20-\mu \mathrm{L}$ reaction was conducted using the iScript cDNA Synthesis Kit (Bio-Rad Laboratories), according to the manufacturer's instructions. Real-time quantitative PCR was performed in triplicate $20-\mu \mathrm{L}$ reactions using SsoAdvanced Universal SYBR Green Super Mix (BioRad Laboratories) according to kit instructions and a final concentration of $500 \mathrm{nM}$ for each primer. Cycling conditions were $95^{\circ} \mathrm{C}$ for $1 \mathrm{~min}$, followed by 40 cycles of $95^{\circ} \mathrm{C}$ for $10 \mathrm{~s}$, annealing temperature for $10 \mathrm{~s}$, and $72^{\circ} \mathrm{C}$ for $30 \mathrm{~s}$, then $95^{\circ} \mathrm{C}$ for $10 \mathrm{~s}$ followed by a melt curve analysis. Primer sequences (Table 1) were designed 
Table 1. Primer sequences and annealing temperatures used for real-time quantitative PCR

\begin{tabular}{|c|c|c|c|c|}
\hline $\begin{array}{l}\text { Gene } \\
\text { symbol }\end{array}$ & Gene name & Sense primer $\left(5^{\prime} \rightarrow 3^{\prime}\right)$ & Antisense primer $\left(5^{\prime} \rightarrow 3^{\prime}\right)$ & $\begin{array}{c}\text { Annealing } \\
\text { temperature } \\
{ }^{\circ} \mathrm{C}\end{array}$ \\
\hline$\overline{G P X 2}$ & Glutathione peroxidase 2 & TCCTGAGCATTCACTGTGCC & CAACCAGAAGGTTGCGGGTA & 59.0 \\
\hline MARVELD2 & Tricellulin & CCGATCTGGGTTTCGGAGC & AGTGTCTGTCCCGATTCCTG & 59.0 \\
\hline TFF3 & Trefoil factor 3 & TTTTCTGAGCAGTCGGGTCC & CCACATACTGCCCGGTTGAA & 59.0 \\
\hline$T L R 2$ & Toll-like receptor 2 & TCCTGTTGCTCCTGCTCAC & GAATCCCGCTCGCTGTAGG & 57.0 \\
\hline TJP1 & Tight junction protein 1 & AATGCATCCTGACCACCAGG & GATGGTGCCGGGTTTGTTTC & 63.0 \\
\hline
\end{tabular}

using primer-BLAST (www.ncbi.nlm.nih.gov/tools/ primer-blast/) except those for OCLN (from Malmuthuge et al., 2013), TJP1 (from Walker et al., 2015), and TNF (from Mookherjee et al., 2006). Primer specificity was validated by direct DNA sequencing (CEQ 8000 GeXP genetic analysis system and DTCS Quick Start Kit, Beckman Coulter Inc., Brea, CA) of gel-purified (Qiagen Gel Extraction Kit) amplicons from a standard end-point PCR reaction. Transcript abundance in samples was based on interpolation from a standard curve evaluated simultaneously with samples as described by Connor et al. (2005). Assay amplification efficiencies ranged from 89.9 to $103.9 \%$, and linearity $\left(\mathrm{R}^{2}\right)$ of standard curves ranged from 0.997 to 1.000 .

\section{Statistical Analyses}

The presence of Giardia was detected in fecal samples of 6 calves during the experimental trial $(\mathrm{n}=1 \mathrm{CON} ; \mathrm{n}$ $=1 \mathrm{INF} ; \mathrm{n}=2 \mathrm{SUC}$; and n = 2 GLP2); thus, Giardia infection status (positive or negative) was included as a main effect and an interaction term in all statistical models. Due to the small number of Giardia-positive animals, no Giardia status-specific interpretations were made when Giardia main effects or interactions were significant. For plasma SAA, FABP-2, and TNF- $\alpha$, treatment means were compared using the MIXED procedure of SAS (version 9.4; SAS Institute Inc., Cary, NC), specifying calf, Giardia infection status, treatment, and day as CLASS variables; in the MODEL statement, plasma analyte was the dependent variable and Giardia status, treatment, day, and the interactions of treatment by day, Giardia by day, Giardia by treatment, and Giardia by treatment by day were the independent effects. Within-calf correlations among days for FABP-2 and TNF- $\alpha$ were modeled using a heterogeneous compound symmetric covariance structure; no correlations were observed for SAA. For all other variables measured at a single time point, treatment means were compared using the GLIMMIX procedure of SAS to fit generalized linear mixed effects models (Stroup, 2015), where Giardia status, calf, and treatment were the CLASS variables and the MODEL statement included the measurement of interest as the dependent variable and Giardia status, treatment, and Giardia by treatment as the independent effects. Jejunal and ileal gene counts, ileal nitrotyrosine as pixels per cell, and fecal oocyst counts were modeled using a negative binomial distribution with log link function. The DSI and ileal nitrotyrosine measured as a percentage of positive cells were modeled using a $\beta$ distribution with logit link function. All other dependent variables were modeled using a normal distribution with identity link function. Significance tests were conducted for the contrasts (1) CON versus INF, (2) INF versus (GLP2 $+\mathrm{SUC}) / 2$, and (3) GLP2 versus SUC.

\section{RESULTS}

All CON calves tested negative for Cryptosporidium by fecal examination throughout the trial, and the experimentally $C$. parvum-infected groups were negative for Cryptosporidium until at least $6 \mathrm{~d}$ after oral inoculation. As expected, INF, SUC, and GLP2 exhibited mild diarrhea in response to $C$. parvum infection. The DSI of INF was greater $(P<0.001)$ than CON and was reduced $(P=0.02)$ in GLP2 and SUC combined relative to INF (Figure 1A). No difference $(P=0.66)$ in DSI was observed between SUC and GLP2. Fecal oocyst counts at slaughter also were reduced $(P=0.09)$ in GLP2 and SUC combined, relative to INF (Figure 1B), despite a limited sample size of 2 calves per treatment group. We found no difference $(P=0.78)$ between GLP2 and SUC in fecal oocyst counts. Mean $( \pm \mathrm{SE})$ ADG $(\mathrm{kg} / \mathrm{d})$ of calves was $0.43( \pm 0.03)$ and gain-tofeed was $0.05( \pm 0.00)$; neither variable differed $(P \geq$ 0.17 ) by experimental treatment.

\section{Plasma Analytes}

Figure 2 summarizes plasma concentrations of FABP2 , TNF- $\alpha$, and SAA throughout the experimental pe- 
riod. We noted no treatment by day interaction $(P>$ 0.32 ) on plasma FABP-2 or TNF- $\alpha$ concentrations, but did note an interaction $(P=0.04)$ for SAA concentration. No effects $(P \geq 0.39)$ of treatment or day were detected on plasma FABP-2 or TNF- $\alpha$ concentrations. For plasma SAA concentration, we observed no differences $(P \geq 0.29)$ among treatments on $\mathrm{d} 1,8$, or 12 , but differences were detected $(P \leq 0.05)$ among treat-
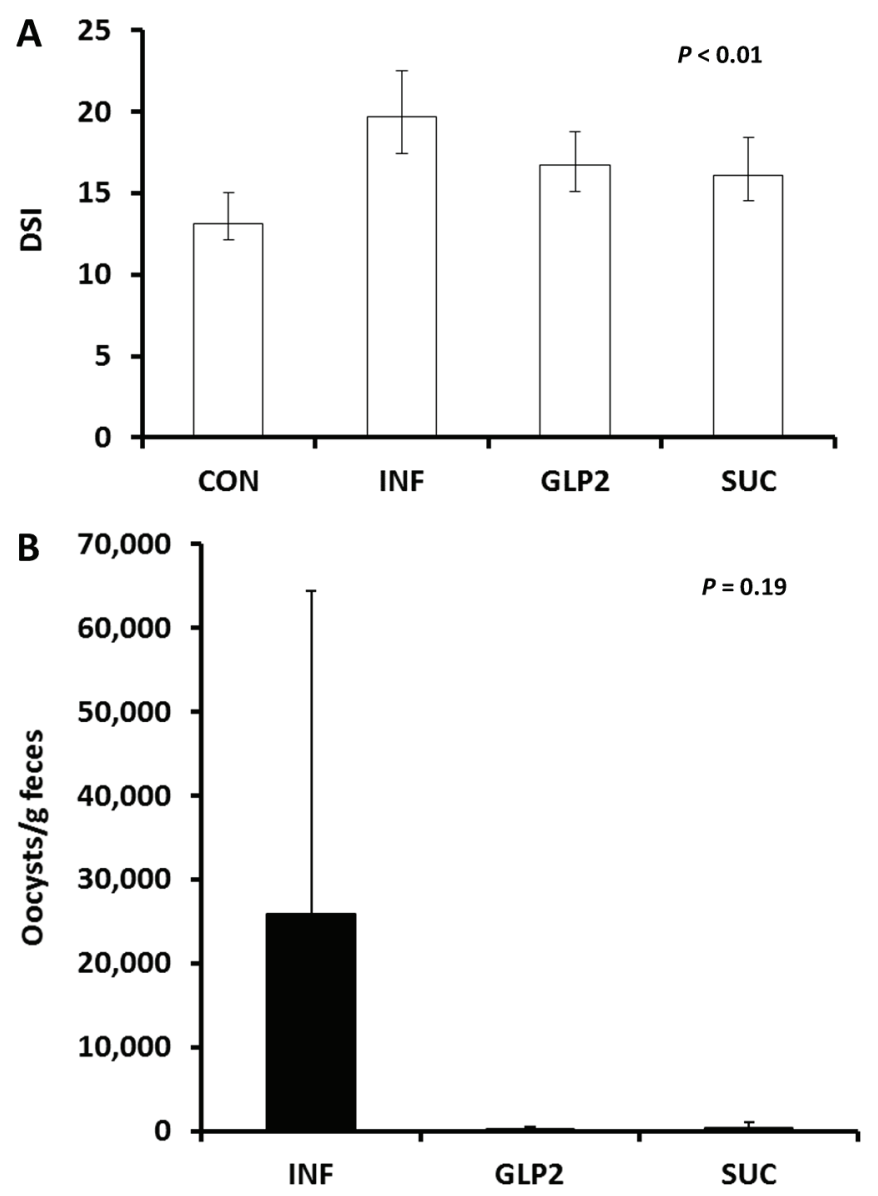

Figure 1. Fecal analyses of noninfected control Holstein bull calves (CON), calves infected with Cryptosporidium parvum (INF), calves infected with $C$. parvum and injected subcutaneously every $12 \mathrm{~h}$ with 50 $\mu \mathrm{g} / \mathrm{kg}$ of BW of glucagon-like peptide 2 beginning $1 \mathrm{wk}$ before infection (GLP2), and calves infected with C. parvum and fed milk replacer supplemented with Sucram (400 mg/kg of DM; Pancosma, Geneva, Switzerland) beginning $1 \mathrm{wk}$ before infection (SUC). (A) Mean diarrhea severity index (DSI) with $95 \% \mathrm{CI} ; \mathrm{n}=6$ /treatment. The DSI is the sum of the daily fecal scores recorded over an 11-d period, where score $1=$ normal; $2=$ stool not formed; $3=$ stool loose and runny; 4 $=$ stool watery with visible solids; and $5=$ stool watery with no visible solids, or bloody. DSI $=11$ indicates normal; DSI $=55$ indicates the worst possible diarrhea. (B) Mean $( \pm \mathrm{SE})$ oocysts per gram of feces on d $18 ; \mathrm{n}=2 /$ treatment. DSI contrasts: INF vs. CON, $P<0.001 ; \mathrm{INF}$ vs. $(\mathrm{GLP} 2+\mathrm{SUC}) / 2, P=0.02$; GLP2 vs. SUC, $P=0.66$; Oocyst shedding contrasts: INF vs. (GLP2 $+\mathrm{SUC}) / 2, P=0.09$; GLP2 vs, SUC, $P=0.78$. ments on d 15 and 18 (Figure 2C). On d 15 and 18, plasma SAA was elevated $(P \leq 0.001)$ in INF relative to CON and was reduced $(P<0.01)$ in SUC and GLP2 combined relative to INF. No difference $(P \geq 0.47)$ was detected in plasma SAA between GLP2 and SUC.

\section{Intestinal Morphometry}

Table 2 summarizes the effects of $C$. parvum infection and GLP-2 or Sucram treatments on intestinal measurements of calves obtained at slaughter. Of all intestinal measures evaluated, only jejunum $1-\mathrm{m}$ section weight was increased $(P=0.04)$ in INF relative to CON. Combined, SUC and GLP2 exhibited increased $(P=0.04)$ mass-to-length ratio and decreased $(P \leq$ $0.03)$ length-to-empty BW ratio in both small and large intestines relative to INF. Ileum 1-m section weight was also greater $(P=0.09)$ in SUC and GLP2 combined versus INF. Total small intestine mass as a percentage of empty BW was reduced $(P<0.01)$ and length-toempty BW ratio in small intestine was decreased $(P=$ 0.06) in SUC relative to GLP2.

Effects of treatment and infection on intestinal villus height are shown in Figure 3. Villus height was reduced in INF relative to CON in both jejunum $(P=0.09)$ and ileum $(P=0.02)$, and was reduced $(P=0.02)$ in ileum of INF relative to SUC and GLP2 combined. We found no difference $(P=0.37)$ in jejunal villus height between INF and SUC and GLP2 combined. Villus height was greater $(P \leq 0.10)$ in GLP2 than SUC in both jejunum and ileum.

\section{Intestinal Apoptosis and Crypt Cell Proliferation}

The percentage of cells undergoing apoptosis, as assessed by TUNEL assay, in crypts and villi of the small intestine are shown in Figure 4. In the jejunum, we observed no effect $(P=0.91)$ of treatment on apoptosis in crypts, but percentage of cells undergoing apoptosis in jejunal villi was increased $(P=0.01)$ in INF relative to $\mathrm{CON}$. We noted no difference $(P \geq 0.76)$ in cellular apoptosis between INF and GLP2 and SUC combined, or between GLP2 and SUC.

In ileum, percentage of apoptotic cells in villi was greater $(P=0.07)$ in INF relative to CON, as well as in GLP2 and SUC combined relative to INF. Apoptosis did not differ $(P=0.96)$ between SUC and GLP2 in ileal villi. In ileal crypts, apoptosis did not differ $(P \geq$ 0.32 ) between INF and CON or between INF and SUC and GLP2 combined. Cellular apoptosis in ileum was reduced $(P=0.02)$ in crypts of SUC relative to GLP2.

Crypt cell proliferation in ileum and jejunum, as measured by positive nuclear staining for BrdU, is sum- 


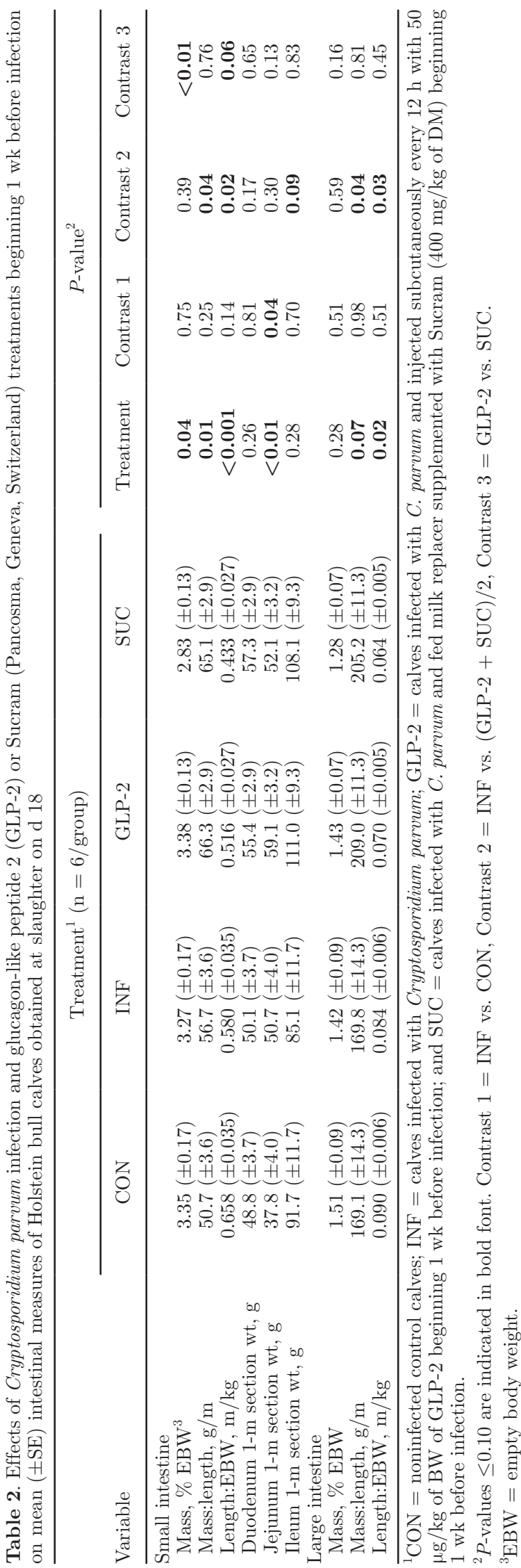

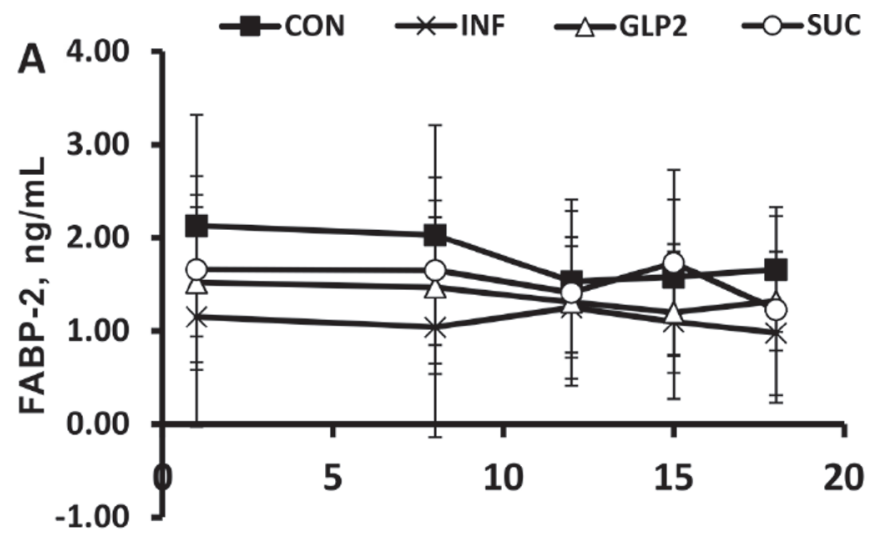
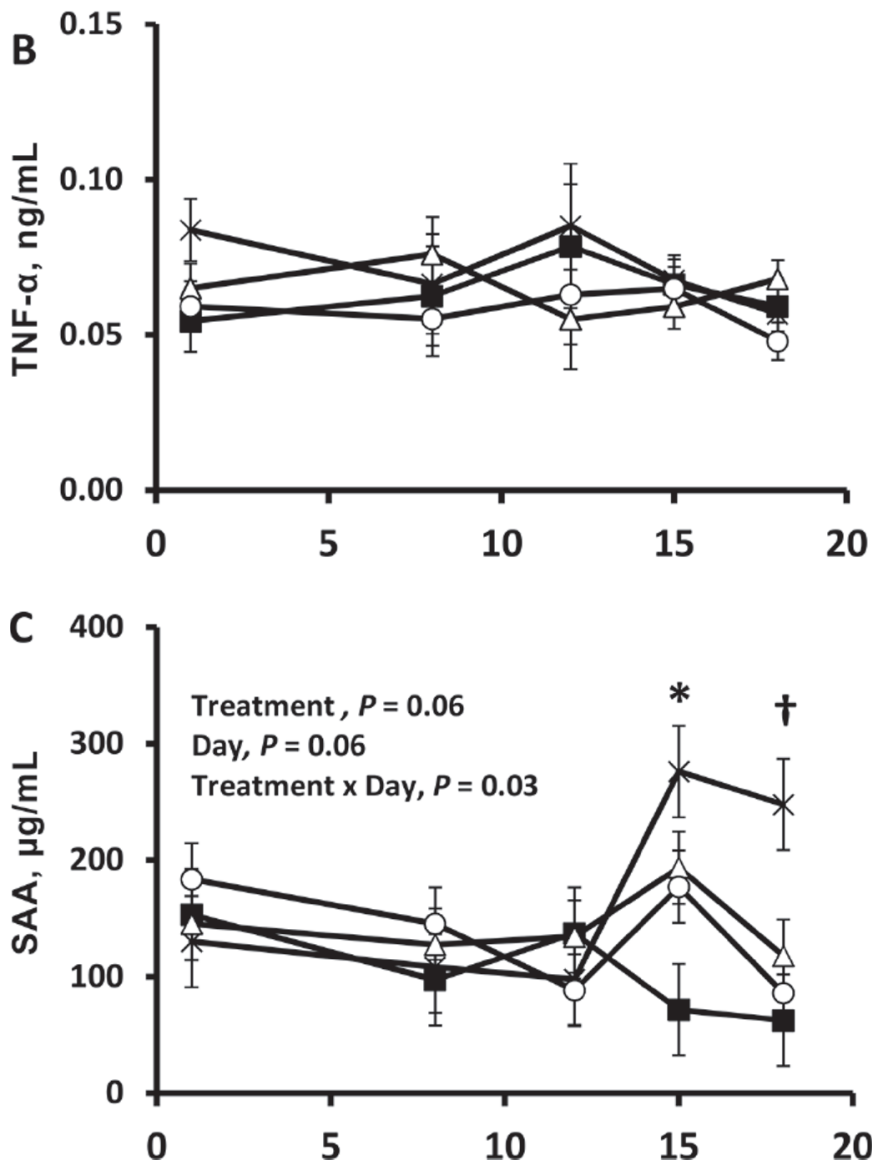

Figure 2. Plasma concentrations (mean $\pm \mathrm{SE}$ ) of fatty acid binding protein 2 (FABP-2), tumor necrosis factor $\alpha$ (TNF- $\alpha$ ), and serum amyloid A (SAA) in noninfected control Holstein bull calves (CON), calves infected with Cryptosporidium parvum (INF), calves infected with C. parvum and injected subcutaneously every $12 \mathrm{~h}$ with $50 \mu \mathrm{g} /$ $\mathrm{kg}$ of BW of glucagon-like peptide 2 beginning 1 wk before infection (GLP2), and calves infected with C. parvum and fed milk replacer supplemented with Sucram (400 mg/kg of DM; Pancosma, Geneva, Switzerland) beginning $1 \mathrm{wk}$ before infection (SUC). All infected calves were orally inoculated with 12,500 C . parvum oocysts on $\mathrm{d}$ 8. Asterisk $(*)$ represents contrasts: INF vs. CON, $P<0.001$; INF vs. $(\mathrm{GLP} 2+\mathrm{SUC}) / 2, P=0.004$; GLP2 vs. SUC, $P=0.02$; dagger (†) represents contrasts: INF vs. CON, $P=0.001$; INF vs. (GLP2 + SUC) $/ 2, P=0.002$; GLP2 vs. SUC, $P=0.47$. 
marized in Figure 5. In jejunum, crypt cell proliferation was greater $(P=0.01)$ in INF relative to $\mathrm{CON}$, and was greater $(P=0.10)$ in INF relative to SUC and GLP2 combined. Cell proliferation in jejunal crypts was similar $(P=0.42)$ between GLP2 and SUC. In ileum, crypt cell proliferation was greater $(P<0.01)$ in INF compared with CON, but did not differ $(P \geq 0.25)$ between INF and GLP2 and SUC combined or between GLP2 and SUC.

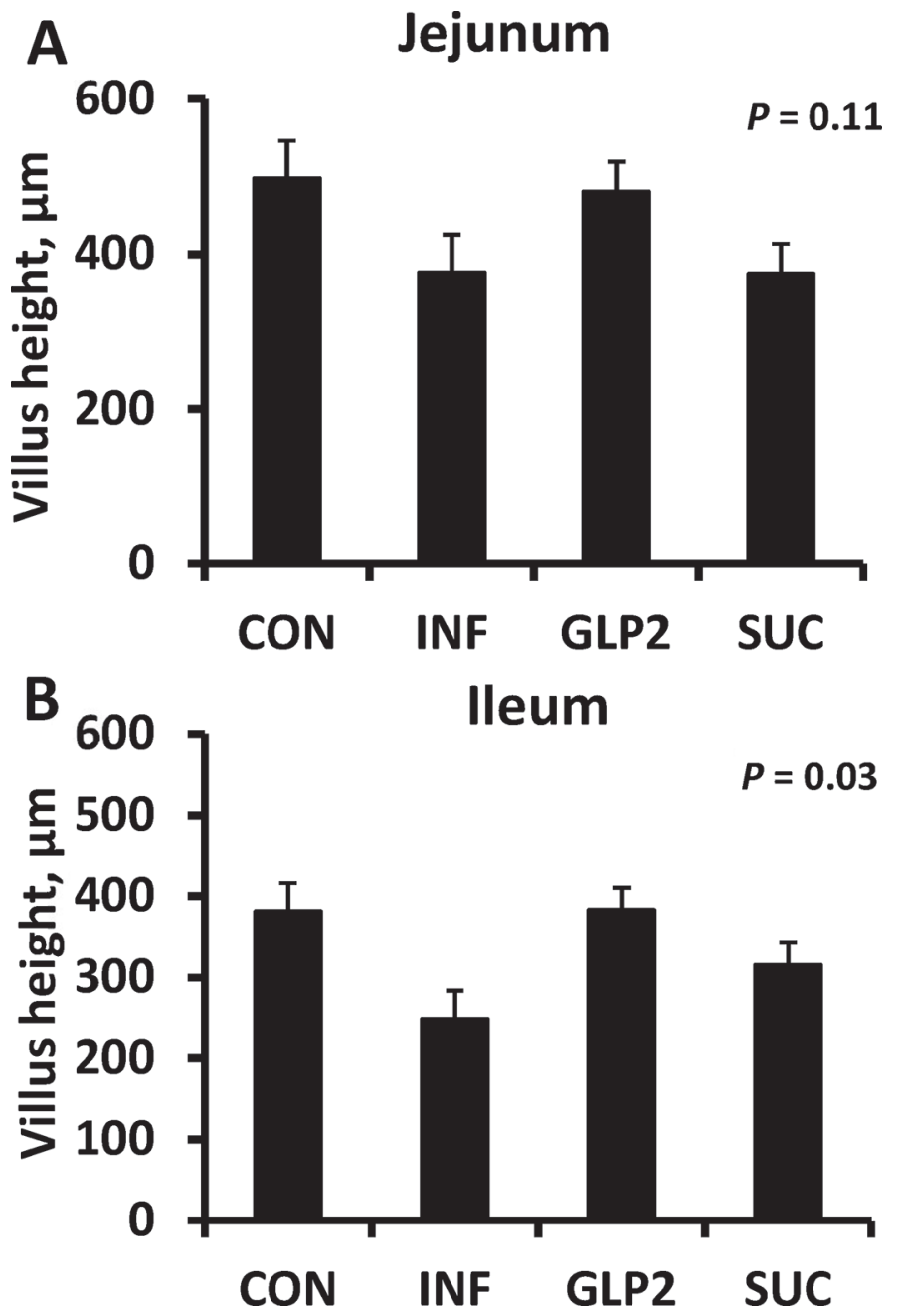

Figure 3. Villus height (mean $\pm \mathrm{SE}$ ) in $(\mathrm{A})$ jejunum and $(\mathrm{B})$ ileum of noninfected control Holstein bull calves (CON), calves infected with Cryptosporidium parvum (INF), calves infected with C. parvum and injected subcutaneously every $12 \mathrm{~h}$ with $50 \mu \mathrm{g} / \mathrm{kg}$ of BW of glucagon-like peptide 2 beginning 1 wk before infection (GLP2), and calves infected with $C$. parvum and fed milk replacer supplemented with Sucram $(400$ $\mathrm{mg} / \mathrm{kg}$ of DM; Pancosma, Geneva, Switzerland) beginning 1 wk before infection (SUC); $\mathrm{n}=6$ /treatment. Jejunum contrasts: INF vs. CON, $P$ $=0.09 ; \mathrm{INF}$ vs. $(\mathrm{GLP} 2+\mathrm{SUC}) / 2, P=0.37$; GLP2 vs. SUC, $P=0.06$; Ileum contrasts: INF vs. CON, $P=0.02$; INF vs. $(\mathrm{GLP} 2+\mathrm{SUC}) / 2$, $P=0.02 ;$ GLP2 vs. SUC, $P=0.10$.
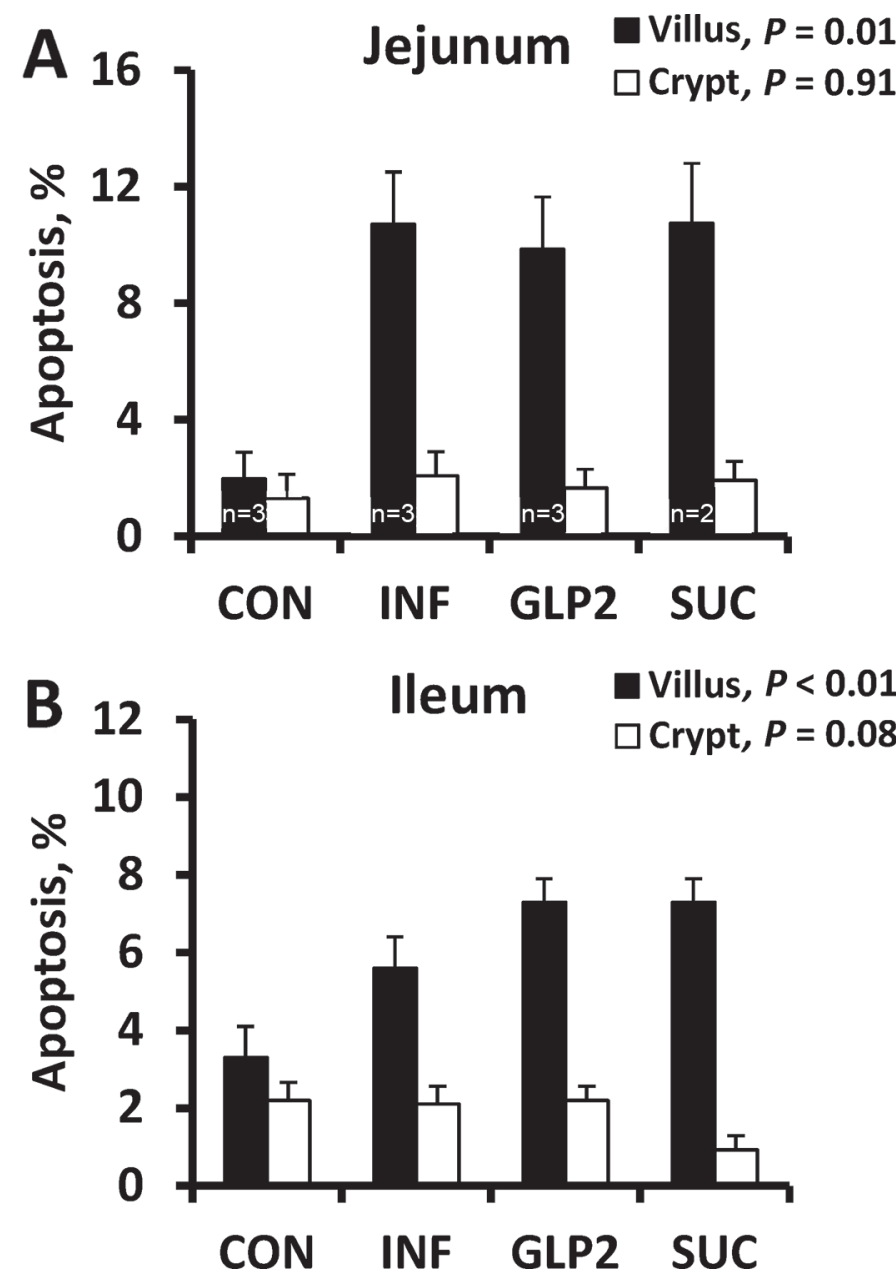

Figure 4. Apoptosis in (A) jejunum and (B) ileum expressed as mean $( \pm \mathrm{SE})$ percentage of cells positive for terminal deoxynucleotidyl transferase end-labeling of non-infected control Holstein bull calves (CON), calves infected with Cryptosporidium parvum (INF), calves infected with $C$. parvum and injected subcutaneously every $12 \mathrm{~h}$ with $50 \mu \mathrm{g} / \mathrm{kg}$ of BW of glucagon-like peptide 2 beginning 1 wk before infection (GLP2), and calves infected with C. parvum and fed milk replacer supplemented with Sucram $(400 \mathrm{mg} / \mathrm{kg}$ of DM; Pancosma, Geneva, Switzerland) beginning 1 wk before infection (SUC); $\mathrm{n}=6$ / treatment unless otherwise indicated. Due to quality and orientation of histological sections from jejunum, fewer than 6 calves per treatment were suitable for cell counting from the TUNEL assay. Jejunal villi contrasts: INF vs. CON, $P=0.01$; INF vs. $(\mathrm{GLP} 2+\mathrm{SUC}) / 2, P$ $=0.86$; GLP2 vs. SUC, $P=0.76$; Ileal villi contrasts: INF vs. CON, $P=0.07$; INF vs. (GLP2 + SUC) $/ 2, P=0.07 ;$ GLP2 vs. SUC, $P=$ 0.96 ; Ileal crypts contrasts: INF vs. CON, $P=0.87$; INF vs. (GLP2 + SUC) $/ 2, P=0.32$; GLP2 vs. SUC, $P=0.02$.

\section{Protein Tyrosine Nitration in Ileum}

Results of ileal nitrated protein immunostaining estimated as number of positive pixels per cell, percentage of positive cells, and positive pixel area are summarized in Table 3. Two of the estimates of tissue nitro-oxidative stress, namely positive pixels per cell and positive 
pixel area, were reduced $(P \leq 0.09)$ in SUC relative to GLP2. No other effects on protein tyrosine nitration were observed.

\section{Intestinal Gene Expression}

Table 4 summarizes mRNA expression of 8 genes of interest (IL18, TNF, GPX2, MARVELD2, TFF3,
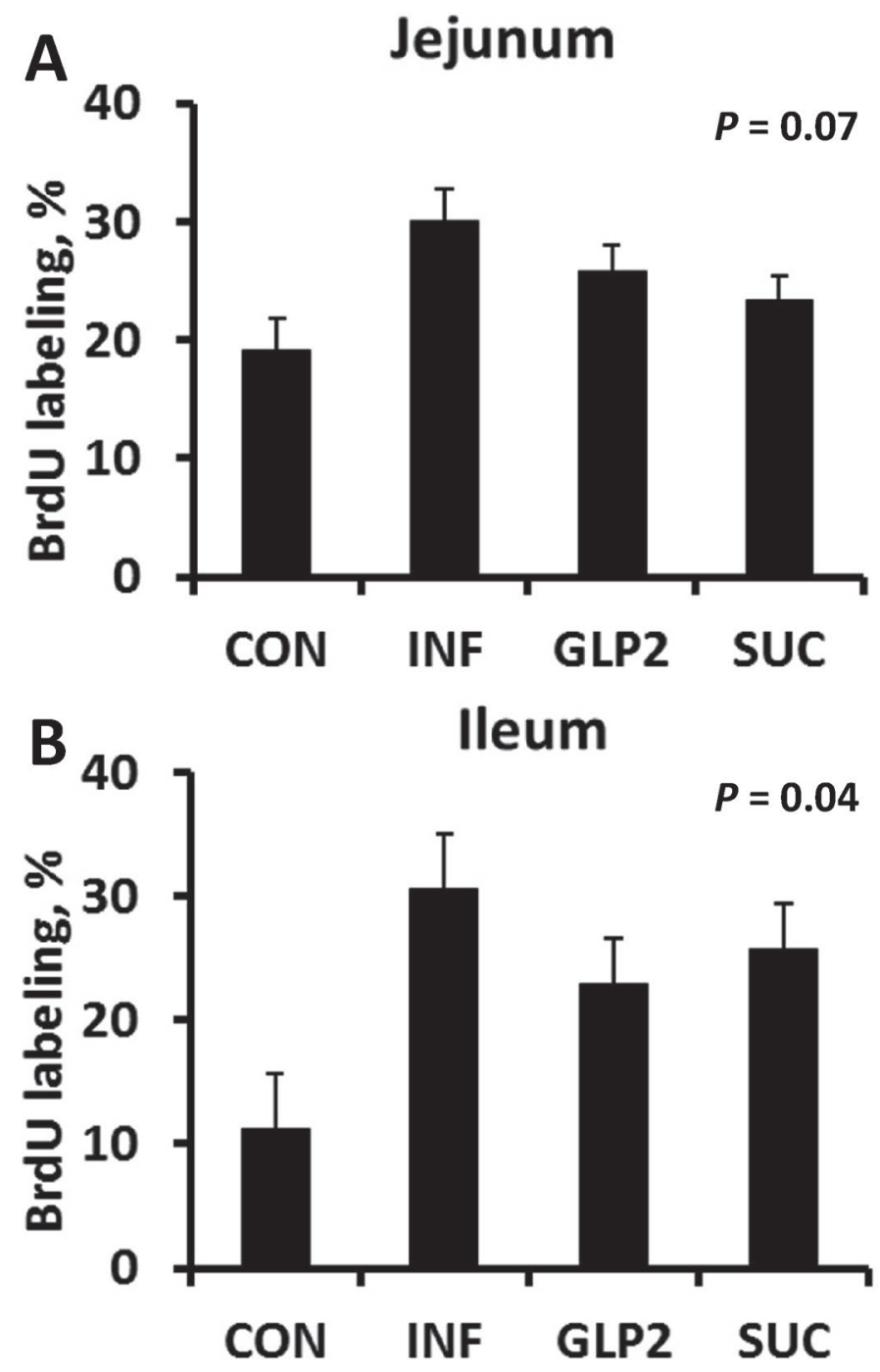

Figure 5. Crypt cell proliferation in (A) jejunum and (B) ileum expressed as mean $( \pm \mathrm{SE})$ percentage of cells positive for 5-bromo2'-deoxyuridine (BrdU) labeling of noninfected control Holstein bull calves (CON), calves infected with Cryptosporidium parvum (INF), calves infected with C. parvum and injected subcutaneously every $12 \mathrm{~h}$ with $50 \mu \mathrm{g} / \mathrm{kg}$ of BW of glucagon-like peptide 2 beginning 1 wk before infection (GLP2), and calves infected with C. parvum and fed milk replacer supplemented with Sucram (400 mg/kg of DM; Pancosma, Geneva, Switzerland) beginning 1 wk before infection (SUC); $\mathrm{n}=6$ / treatment. Jejunum contrasts: INF vs. CON, $P=0.01$; INF vs. (GLP2 $+\mathrm{SUC}) / 2, P=0.10$; GLP2 vs. SUC, $P=0.42$; Ileum contrasts: INF vs. CON, $P<0.01$; INF vs. (GLP2 $+\mathrm{SUC}) / 2, P=0.25$; GLP2 vs. SUC, $P=0.59$.
OCLN, TLR2, and TJP1) by treatment group in jejunum and ileum of calves evaluated on d 18 of the study. In jejunum, we found no treatment effect $(P=0.60)$ on TLR2 mRNA expression, but expression of $I L 18$, GPX2, and MARVELD2 was increased $(P \leq 0.02)$ and $T N F$ was decreased $(P=0.02)$ in INF versus CON. Among these genes, only MARVELD2 mRNA expression in jejunum was reduced $(P=0.01)$ in SUC and GLP2 combined relative to INF. The mRNA expression of MARVELD2 was no different $(P=0.97)$ in GLP than in SUC, but expression of GPX2 was reduced ( $P$ $=0.01)$ in GLP2 relative to SUC. The mRNA expression of TFF3, OCLN, and TJP1 was not different $(P$ $\geq 0.25)$ in jejunum of INF relative to CON or in GLP2 versus SUC, although expression of these transcripts was reduced $(P \leq 0.08)$ in GLP2 and SUC combined compared with INF. As in jejunum, mRNA expression of GPX2 and MARVELD2 was increased $(P \leq 0.03)$ in INF versus CON. The GPX2 mRNA expression in ileum was reduced $(P=0.02)$ in GLP2 and SUC combined relative to INF; however, no difference $(P=0.95)$ in GPX2 mRNA expression was detected between $\mathrm{SUC}$ and GLP2 in ileum.

\section{DISCUSSION}

In the United States, Cryptosporidium is the most common diarrhea-causing pathogen in newborn calves, wherein the most prevalent form is C. parvum (Santín et al., 2004). The prepatent period of $C$. parvum in ruminants is about $4 \mathrm{~d}$, and peak shedding of oocysts typically occurs at approximately 2 wk of age during natural infections (Thompson et al., 2008). Cryptosporidiosis may cause mucous or watery diarrhea lasting 4 to $14 \mathrm{~d}$ or be asymptomatic, but pathology associated with infection includes atrophy of intestinal villi, reduced gut barrier function, altered apoptosis rate of mucosal cells, and inflammation (Thompson et al., 2008). In the present study, calves orally infected with 12,500 C. parvum oocysts exhibited mild diarrhea and a significant increase in DSI compared with noninfected control calves. However, in general, infected calves treated daily with GLP-2 or Sucram beginning 1 wk before oral inoculation had a reduced DSI compared with nontreated, infected calves, suggesting that both treatments may provide some protection to the damaging effects of C. parvum on the gut. Furthermore, fecal analysis of a subset of GLP-2 and Sucram-fed calves suggested these treatments may contribute to reduced number of Cryptosporidium oocysts shed per gram of feces on d 10 of infection. Based on results from the 2 observed calves per treatment (mean $\pm \mathrm{SE}$; INF $=25,814 \pm 38,656$, GLP2 $=212 \pm 318$, and SUC $=$ $400 \pm 599$ ), a post-hoc power analysis indicated 4 or 
Table 3. Effects of Cryptosporidium parvum infection and glucagon-like peptide 2 (GLP-2) or Sucram (Pancosma, Geneva, Switzerland) treatments beginning 1 wk before infection on mean $( \pm \mathrm{SE})$ protein tyrosine nitration immunostaining in ileum of Holstein bull calves at d 18

\begin{tabular}{|c|c|c|c|c|c|c|c|c|}
\hline \multirow[b]{2}{*}{ Variable } & \multicolumn{4}{|c|}{ Treatment $^{1}(\mathrm{n}=6 /$ group$)$} & \multicolumn{4}{|c|}{$P$-value ${ }^{2}$} \\
\hline & $\mathrm{CON}$ & INF & GLP2 & SUC & Treatment & Contrast 1 & Contrast 2 & Contrast 3 \\
\hline$\%$ Positive & $29.8( \pm 5.2)$ & $26.0( \pm 4.9)$ & $33.5( \pm 4.4)$ & $24.3( \pm 3.9)$ & 0.45 & 0.61 & 0.66 & 0.14 \\
\hline Positive area & $217.6( \pm 15.9)$ & $227.4( \pm 15.9)$ & $241.6( \pm 12.6)$ & $206.4( \pm 12.6)$ & 0.29 & 0.67 & 0.85 & 0.06 \\
\hline
\end{tabular}

${ }^{1} \mathrm{CON}=$ noninfected control calves; INF = calves infected with Cryptosporidium parvum; GLP-2 = calves infected with C. parvum and injected subcutaneously every $12 \mathrm{~h}$ with $50 \mu \mathrm{g} / \mathrm{kg}$ of BW of GLP-2 beginning 1 wk before infection; and SUC = calves infected with $C$. parvum and fed milk replacer supplemented with Sucram $(400 \mathrm{mg} / \mathrm{kg}$ of DM) beginning 1 wk before infection.

${ }^{2} P$-values $\leq 0.10$ are indicated in bold font. Contrast $1=\mathrm{INF}$ vs. CON, Contrast $2=\mathrm{INF}$ vs. (GLP- $\left.2+\mathrm{SUC}\right) / 2$, Contrast $3=\mathrm{GLP}-2$ vs. SUC.

more calves per treatment would allow the observed difference between INF and GLP2 to be detected as statistically significant. Similarly, 5 or more calves per treatment would allow the observed difference between INF and SUC to be detected as statistically significant. Hence, the 2 calves per treatment means comparisons of INF versus SUC $(P=0.14)$ and GLP2 $(P=0.11)$ suggests potential reduction in fecal oocyst counts with these treatments may have been detected with a larger sample size and are of biological interest.

Because GLP-2 has been shown to affect expression of tight junctions in epithelial cells of the intestine ( $\mathrm{Yu}$ et al., 2014; Walker et al., 2015), treatment may reduce the ability of C. parvum to attach to the microvilli and penetrate the host epithelium. Alternatively, Costa et al. (2011) demonstrated that well-nourished weaned mice challenged with $C$. parvum shed fewer fecal oocysts and for a shorter duration than malnourished infected mice. Thus, effects of GLP-2 and Sucram on DSI may be related to their effects on the calf's nutrient status, as both GLP-2 and Sucram are known to increase intestinal nutrient transport and absorption (Moran et al., 2014; Connor et al., 2015). Clearly, additional study is needed to determine whether GLP-2 or Sucram treatments consistently reduce DSI in cryptosporidiosis or could affect oocyst shedding, as well as their mechanisms of action.

Plasma indicators of impaired intestinal integrity (FABP-2) and the acute phase response (TNF- $\alpha$ ) evaluated in infected calves relative to noninfected controls showed no significant changes in plasma concentrations over time or by treatment through d 10 of $C$. parvum infection despite a significant increase in DSI. Circulating concentrations of FABP-2 are elevated in neonatal humans with necrotizing enterocolitis (Schurink et al., 2015) and patients with celiac disease and villus atrophy (Derikx et al., 2009; Adriaanse et al., 2013), as the binding protein is primarily produced by epithelial cells of the small intestine and is released into circulation during gut damage (Bottasso Arias et al., 2015). No studies to date have examined relationships between intestinal disease or damage and circulating FABP-2 in cattle, although we anticipate similar relationships to those observed in humans. Failure to detect a change in FABP-2 in C. parvum-infected calves indicates that plasma FABP-2 may not be a reliable indicator of intestinal damage in cattle or that calves in our study did not have sufficient mucosal injury to significantly increase circulating FABP-2 concentration. Previous work in similarly aged Holstein calves to those in the present study and infected with a much larger infective dose of $C$. parvum $\left(5 \times 10^{5}\right.$ oocysts $)$ showed intestinal permeability more than double when measured $7 \mathrm{~d}$ postinfection, which remained elevated through $14 \mathrm{~d}$ postinfection (Klein et al., 2008).

Previous studies of humans and mice during experimentally induced cryptosporidiosis reported increased local TNF mRNA production within the intestinal mucosa (Lacroix et al., 2001; Robinson et al., 2001; Ehigiator et al., 2005), as well as increased systemic TNF- $\alpha$ in children naturally infected with Cryptosporidium (Kirkpatrick et al., 2006) relative to healthy individuals. Incubation of isolated bovine PMNL with C. parvum also increased TNF gene transcription (Muñoz-Caro et al., 2015), and experimental C. parvum inoculation of BALB/C mice with $10^{6}$ oocysts increased serum TNF- $\alpha$ concentration (Codices et al., 2013). In our study, plasma TNF- $\alpha$ levels of calves indicated that the cryptosporidiosis induced by an inoculation with 12,500 oocysts was not sufficient to elicit systemic inflammation and TNF mRNA was actually reduced at this time point. Furthermore, we evaluated the local inflammatory response in the jejunum and ileum by examining TLR2 and IL18 mRNA expression. In previous studies, TLR2 mRNA was upregulated in cultured bovine intestinal epithelial cells exposed to $C$. parvum, which is believed to serve as an initial activator of the innate immune response to exposure to the parasite (Yang et al., 2015). Similarly, expression of the proinflammatory response gene IL18 was increased in human primary intestinal epithelial cells in response to C. parvum infection (McDonald et al., 2006), and 
CONNOR ET AL.

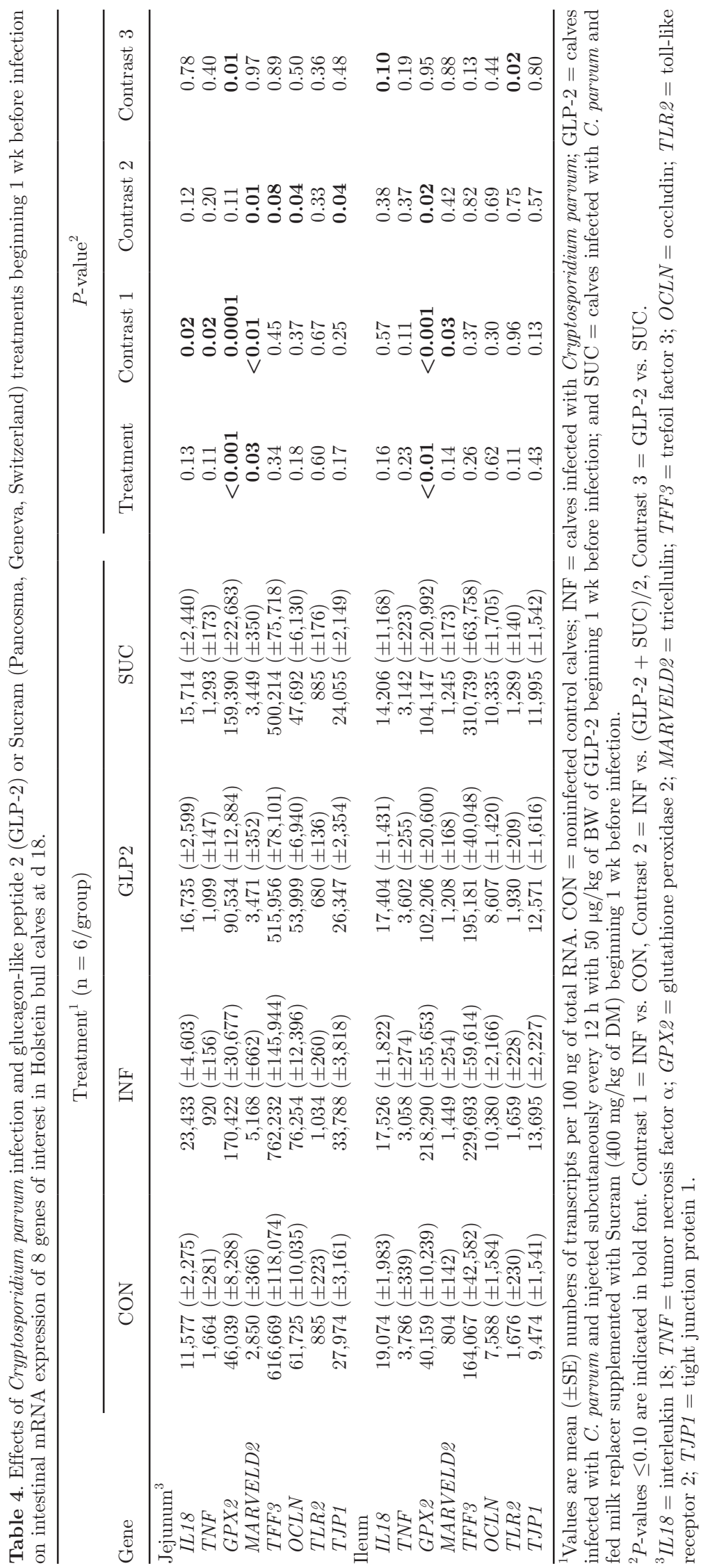


at $3 \mathrm{~d}$ postinfection in mice with an impaired $\mathrm{TH}-1$ immune response (Ehigiator et al., 2005). In our calves, we observed no detectable changes in TLR2 mRNA in response to $C$. parvum measured $10 \mathrm{~d}$ postinfection, although this time point may have been too late to detect the tissue response to infection. Sucram-treated calves did exhibit lower TLR2 mRNA in ileum relative to GLP-2-treated calves, but similar effects were not observed in jejunum. We did observe an increase in $I L 18$ mRNA in calf jejunum of infected calves, consistent with responses in humans, but treatments with GLP-2 and Sucram showed no significant benefits on intestinal IL18 transcript abundance even though IL18 mRNA tended to be reduced in ileum of Sucram-treated calves relative to those receiving GLP-2.

Unlike plasma FABP-2 and TNF- $\alpha$, we did observe increased abundance of the acute phase plasma marker SAA in C. parvum-infected calves versus noninfected controls by d 15 of the study ( 8 d postinoculation). Serum amyloid $\mathrm{A}$ has been shown to increase in animals exhibiting diarrhea caused by $C$. parvum and rotavirus (Enemark et al., 2003). The GLP-2- and Sucram-treated calves, however, exhibited reduced SAA concentrations relative to infected controls on $\mathrm{d} 15$ and 18 . These findings suggest that the GLP-2 and Sucram treatments may contribute to a shortened duration of intestinal injury in response to $C$. parvum infection.

To evaluate possible means by which GLP-2 and Sucram treatments may be reducing intestinal effects of $C$. parvum infection, we evaluated mRNA expression of tight junction protein genes MARVELD2, OCLN, and TJP1, antioxidant gene GPX2, as well as TFF3, a mucin-associated protein that helps to maintain integrity of the intestinal epithelium and promote healing of damaged cells (Hoffmann et al., 2001). Moran et al. (2012) reported that a human colon cell line treated with GLP-2 reduced cellular permeability, which was associated with increased expression of the tight junction proteins occludin and tight junction protein 1 , and diminished the detrimental effects of TNF- $\alpha$ treatment on cellular barrier function. In addition, GLP-2 treatment of porcine jejunal epithelium increased expression of OCLN and TJP1 mRNA and proteins ( $\mathrm{Yu}$ et al., 2014). We previously observed reduced expression of tight junction protein genes in intestinal segments of newborn calves infected with the coccidian parasite $E i$ meria bovis, and restored tight junction gene expression in infected calves treated with GLP-2 for $10 \mathrm{~d}$, beginning after signs of clinical disease (Walker et al., 2015). In the current study, calves were treated with GLP-2 and Sucram for $7 \mathrm{~d}$ before oral inoculation with $C$. parvum and each day thereafter for $10 \mathrm{~d}$. Under these conditions, we did not detect any changes in $O C L N$ or TJP1 mRNA in ileum with infection or experimental treatment, but did observe reductions in OCLN and TJP1 mRNA jejunum in GLP-2- and Sucram-treated calves relative to infected controls. In addition, we observed an increase in MARVELD2 mRNA expression in both ileum jejunum of $C$. parvum-infected calves, which was eliminated in jejunum by GLP-2 and Sucram treatments. The MARVELD2 gene encodes tricellulin, a protein that helps to regulate permeability and barrier function at multicellular junctions of epithelial membranes (Mariano et al., 2011). Increased expression of intestinal epithelial MARVELD2 mRNA in response to infection may reflect local remodeling and recovery of cellular membranes occurring after disruption of the mucosal layer caused by $C$. parvum, or perhaps a host defense response to reinforce intestinal barrier function against further pathogen invasion. Reduction of MARVELD2, OCLN, and TJP1 mRNA with GLP-2 and Sucram treatments during $C$. parvum infection suggests that these treatments may help to protect the host from changes in intestinal integrity and local cellular remodeling induced by infection.

Furthermore, we observed increased expression of GPX2 mRNA in both jejunum and ileum of infected control calves, which was attenuated in ileum by GLP-2 and Sucram treatments and was reduced in jejunum of GLP-2-treated calves relative to those receiving $\mathrm{Su}$ cram. Induction of GPX2 expression has been demonstrated in a mouse model of acute colitis and is believed to contribute to tissue recovery after inflammation (Hiller et al., 2015). Thus, our results indicate some level of intestinal inflammation or injury was induced by $C$. parvum infection, which was mitigated in calves treated with GLP-2 and Sucram before inoculation. Despite responses in tight junction protein mRNA and GPX2 transcript expression, we observed no treatment effects on TFF3 mRNA expression in ileum, and only a tendency for reduced TFF3 expression in jejunum of infected calves receiving GLP-2 and Sucram relative to infected controls. A preliminary study using 2 piglet models of short bowel syndrome indicated that GLP2 treatment increases expression of TFF3 mRNA and may assist with tissue repair after injury (Koepke et al., 2015). Thus, changes in TFF3 mRNA expression did not appear to play a significant role in response to C. parvum infection or GLP-2 and Sucram treatments in our study.

Consistent with observed changes in gene expression related to gut injury and integrity as well as plasma SAA results, we detected intestinal disruption and mucosal damage in infected control calves relative to noninfected controls, which were congruent with an established C. parvum infection (Gookin et al., 2002). These disruptions included reduced intestinal villus height, increased apoptosis in villi, and increased cell prolifera- 
tion in intestinal crypts. Shortening and fusion of villi results from loss of epithelium at the villus surface as the invading parasites replicate and invade neighboring microvilli (Tzipori and Ward, 2002). Stimulation of cell proliferation then follows in the intestinal crypts, which serve as the site of stem cell-mediated villus regeneration (Neal et al., 2011). It is believed that apoptosis is increased by the host in late infection as a protective mechanism to limit replication of the intracellular parasites and to minimize inflammation associated with cell injury or necrosis (Liu et al., 2008). Similar to rodents and swine (Drucker and Yusta, 2014; Deng et al., 2016), treatment of healthy ruminating calves with GLP-2 increases villus height (Taylor-Edwards et al., 2011) and has been shown to reduce cell apoptosis in villi and crypts of newborn pigs receiving total parenteral nutrition (Burrin et al., 2005). In the present study, treatment of infected calves with GLP-2 and Sucram maintained villus height in ileum, although GLP-2 effects on intestinal villus height tended to be greater than the effects of Sucram. Moran et al. (2014) reported that Sucram feeding increased both villus height and crypt depth in duodenum of ruminating calves, but failed to alter either measure in preruminating calves, suggesting the response may be affected by age or developmental stage. Increased apoptosis in villi of small intestine associated with C. parvum infection was not reduced by GLP-2 and Sucram treatments, but tended to increase apoptosis in ileal villi. Sucram feeding did reduce apoptosis in ileal crypts relative to GLP-2, suggesting potential reduction in damage to this region with Sucram treatment. It is noteworthy that Liu et al. (2008) reported the capability of intracellular C. parvum to inhibit apoptosis within epithelial cells to limit its host's ability to defend against pathogen replication. Thus, the observed increase in apoptosis in ileal villi of Sucram- and GLP-2-treated calves may reflect a reduction of intracellular C. parvum in villi of these animals. Furthermore, GLP-2 and Sucram treatments tended to reduce cell proliferation in jejunal crypts induced by infection. This reduction in crypt cell proliferation may reflect a diminished requirement for cell replacement from C. parvum-induced mucosal injury.

On a gross tissue level, GLP-2 and Sucram treatments increased the mass-to-length ratio and reduced length-to-empty BW ratio of both the small and large intestines relative to infected controls, indicating the tissues were more dense and shorter as a result of GLP2 and Sucram treatments. Additionally, Sucram feeding reduced the mass and length of the small intestine (normalized to empty BW) relative to GLP-2 treatment, indicating an overall reduction in the relative size of the small intestine and potential benefits to energetic efficiency in this group, given the high metabolic de- mands of intestinal tissue (Baldwin et al., 2004). To date, no other studies have evaluated intestinal size in response to Sucram feeding, but ruminating calves treated for the same duration and dose of GLP-2 used in the present study showed no change in length-toempty BW ratio of either the small or large intestine (Taylor-Edwards et al., 2011; Connor et al., 2013). Thus, the reason for the observed reductions in the present study is unknown. Nonetheless, it is interesting to consider that Allen (1984) proposed that Eimeria acervulina-infected chickens exhibiting greater mass of the distal small intestine relative to controls may be expressing a compensatory response of the tissue to its reduced nutrient uptake functions during disease. Because Sucram and GLP-2 treatments increase expression of glucose transporters and increase glucose uptake and mucosal growth (Cheeseman, 1997; TaylorEdwards et al., 2011; Moran et al., 2014), perhaps a corresponding reduction in overall intestinal size can be afforded by the animal while maintaining sufficient nutrient absorption. Further study is needed regarding the effects of Sucram and GLP-2 treatments on overall intestinal size in cattle, particularly during coccidiosis and potential longer-term gains in growth performance. Lastly, increased 1-m section weights of the jejunum in C. parvum-infected control calves relative to noninfected controls likely was related to symptomatic thickening of the folds of the small intestine associated with the disease (Federle and Raman, 2015), and no significant benefits of GLP-2 and Sucram treatments on this measure were detected.

Finally, we observed no main effects of infection or treatment on nitro-oxidative stress in the ileum of calves, measured as nitrated protein abundance, although 2 estimates of nitrated protein abundance tended to be reduced in Sucram-treated calves relative to those administered GLP-2. We previously demonstrated an increase in nitro-oxidative stress in ileocecum of calves infected with $E$. bovis, which was greatly reduced (47 to $69 \%$ ) with GLP-2 therapy (Connor et al., 2013). Not surprisingly, no benefits of GLP-2 treatment in reducing inflammation-related nitro-oxidative stress among noninfected control calves were found in that study. In the present study, nitrated protein abundance was highly variable among calves within each group, and it appeared that the tissue inflammatory response to infection was too small to elicit a significant increase in nitro-oxidative stress to evaluate mitigation potential by GLP-2 and Sucram treatments. More severe coccidial infection is needed to effectively assess the antiinflammatory effects of these treatments in cattle.

In conclusion, GLP-2 and Sucram treatment of calves before oral inoculation with 12,500 C. parvum oocysts showed some protection relative to untreated infected 
calves, including reduced diarrhea, improved intestinal morphology, a reduced plasma indicator of inflammation, and reduced mRNA expression of genes participating in cellular remodeling and injury repair. For the majority of variables examined, no clear difference was evident between the effects of GLP-2 versus Sucram. Additional evaluation of these therapies is needed in calves with more severe cases of coccidiosis to more effectively determine their beneficial effects.

\section{ACKNOWLEDGMENTS}

Financial support was provided by Pancosma SA and Agricultural Research Service Project 8042-31320077-00D. We are grateful for the excellent technical assistance of Mary Bowman, Donald Carbaugh, Chuck Lowe, Jim Piatt, Research Support Services, Mary Niland, Dennis Hucht, Natalia Macarisin, and Aleksey Molokin of the USDA-Agricultural Research Service (Beltsville, MD). Mention of trade names or commercial products in this article is solely for the purpose of providing specific information and does not imply recommendation or endorsement by the USDA. The USDA is an equal opportunity provider and employer.

\section{REFERENCES}

Adriaanse, M. P., G. J. Tack, V. L. Passos, J. G. Damoiseaux, M. W. Schreurs, K. van Wijck, R. G. Riedl, A. A. Masclee, W. A. Buurman, C. J. Mulder, and A. C. Vreugdenhil. 2013. Serum I-FABP as marker for enterocyte damage in celiac disease and its relation to villous atrophy and circulating autoantibodies. Aliment. Pharmacol. Ther. 37:482-490.

Allen, P. C. 1984. Physiological responses of chicken gut tissue to infection with Eimeria acervulina. Avian Dis. 28:868-876.

Bottasso Arias, N. M., M. García, C. Bondar, L. Guzman, A. Redondo, N. Chopita, B. Córsico, and F. G. Chirdo. 2015. Expression pattern of fatty acid binding proteins in celiac disease enteropathy. Mediators Inflamm. 2015:738563.

Baldwin, R. L., VI, K. R. McLeod, J. L. Klotz, and R. N. Heitmann. 2004. Rumen development, intestinal growth and hepatic metabolism in the pre- and postweaning ruminant. J. Dairy Sci. 87(E. Suppl.):55-65.

Bancroft, J. D., and A. Stevens. 1982. Theory and Practice of Histological Techniques. 2nd ed. Churchill Livingstone, London, UK.

Burrin, D. G., B. Stoll, X. Guan, L. Cui, X. Chang, and J. J. Holst. 2005. Glucagon-like peptide 2 dose-dependently activates intestinal cell survival and proliferation in neonatal piglets. Endocrinology 146:22-32.

Cheeseman, C. I. 1997. Upregulation of SGLT-1 transport activity in rat jejunum induced by GLP-2 infusion in vivo. Am. J. Physiol. 273:R1965-R1971.

Cho, Y. I., and K.-J. Yoon. 2014. An overview of calf diarrhea-Infectious etiology, diagnosis, and intervention. J. Vet. Sci. 15:1-17.

Codices, V., C. Martins, C. Novo, B. de Sousa, Â. Lopes, M. Borrego, and O. Matos. 2013. Dynamics of cytokines and immunoglobulins serum profiles in primary and secondary Cryptosporidium parvum infection: Usefulness of Luminex xMAP technology. Exp. Parasitol. 133:106-113.

Connor, E. E., C. M. Evock-Clover, M. P. Walker, T. H. Elsasser, and S. Kahl. 2015. Comparative gut physiology symposium: Comparative physiology of glucagon-like peptide-2: Implications and ap- plications for production and health of ruminants. J. Anim. Sci. 93:492-501.

Connor, E. E., S. Kahl, T. H. Elsasser, R. L. Baldwin 6th, R. Fayer, M. Santín-Duran, G. L. Sample, and C. M. Evock-Clover. 2013. Glucagon-like peptide 2 therapy reduces negative effects of diarrhea on calf gut. J. Dairy Sci. 96:1793-1802.

Connor, E. E., D. L. Wood, T. S. Sonstegard, A. F. da Mota, G. L. Bennett, J. L. Williams, and A. V. Capuco. 2005. Chromosomal mapping and quantitative analysis of estrogen-related receptor alpha-1, estrogen receptors alpha and beta and progesterone receptor in the bovine mammary gland. J. Endocrinol. 185:593-603.

Costa, L. B., E. A. JohnBull, J. T. Reeves, J. E. Sevilleja, R. S. Freire, P. S. Hoffman, A. A. M. Lima, R. B. Oriá, J. K. Roche, R. L. Guerrant, and C. A. Warren. 2011. Cryptosporidium-malnutrition interactions: mucosal disruption, cytokines, and TLR signaling in a weaned murine model. J. Parasitol. 97:1113-1120.

De Waele, V., N. Speybroeck, D. Berkvens, G. Mulcahy, and T. M. Murphy. 2010. Control of cryptosporidiosis in neonatal calves: Use of halofuginone lactate in two different calf rearing systems. Prev. Vet. Med. 96:143-151.

Deng, Q. H., G. Jia, H. Zhao, Z. L. Chen, X. L. Chen, G. M. Liu, and K. N. Wang. 2016. The prolonged effect of glucagon-like peptide 2 pretreatment on growth performance and intestinal development of weaned piglets. J. Anim. Sci. Biotechnol. 7:28.

Derikx, J. P., A. C. Vreugdenhil, A. M. Van den Neucker, J. Grootjans, A. A. van Bijnen, J. G. Damoiseaux, L. W. van Heurn, E. Heineman, and W. A. Buurman. 2009. A pilot study on the noninvasive evaluation of intestinal damage in celiac disease using I-FABP and L-FABP. J. Clin. Gastroenterol. 43:727-733.

Drucker, D. J., and B. Yusta. 2014. Physiology and pharmacology of the enteroendocrine hormone glucagon-like peptide-2. Annu. Rev. Physiol. 76:561-583.

Ehigiator, H. N., P. Romagnoli, K. Borgelt, M. Fernandez, N. Mcnair, W. E. Secor, and J. R. Mead. 2005. Mucosal cytokine and antigen-specific responses to Cryptosporidium parvum in IL-12p40 KO mice. Parasite Immunol. 27:17-28.

Elsasser, T. H., S. Kahl, C.-J. Li, J. L. Sartin, W. M. Garrett, and J. Rodrigo. 2007. Caveolae nitration of JAK-2 at the 1007Y-1008Y site: Coordinating inflammatory response and metabolic hormone readjustment within the somatotropic axis. Endocrinology 148:3803-3813.

Enemark, H. L., V. Bille-Hansen, P. Lind, P. M. H. Heegaard, H. Vigre, P. Ahrens, and S. M. Thamsborg. 2003. Pathogenicity of Cryptosporidium parvum - Evaluation of an animal infection model. Vet. Parasitol. 113:35-57.

Federle, M. P., and S. P. Raman, eds. 2015. Diagnostic Imaging: Gastrointestinal. 3rd ed. Elsevier Health Sciences, Philadelphia, PA.

Gookin, J. L., S. K. Nordone, and R. A. Argenzio. 2002. Host responses to Cryptosporidium infection. J. Vet. Intern. Med. 16:12-21.

Hiller, F., K. Besselt, S. Deubel, R. Brigelius-Flohé, and A. P. Kipp. 2015. GPx2 induction is mediated through STAT transcription factors during acute colitis. Inflamm. Bowel Dis. 21:2078-2089.

Hoffmann, W., W. Jagla, and A. Wiede. 2001. Molecular medicine of TFF-peptides: From gut to brain. Histol. Histopathol. 16:319-334.

Jarvie, B. D., L. A. Trotz-Williams, D. R. McKnight, K. E. Leslie, M. M. Wallace, C. G. Todd, P. H. Sharpe, and A. S. Peregrine. 2005. Effect of halofuginone lactate on the occurrence of Cryptosporidium parvum and growth of neonatal dairy calves. J. Dairy Sci. 88:1801-1806.

Kahn, C. M., and S. Line, eds. 2010. The Merck Veterinary Manual. 10th ed. Merck and Company Inc., Whitehouse Station, NJ.

Kenison, D. C., T. H. Elsasser, and R. Fayer. 1990. Radioimmunoassay for bovine tumor necrosis factor: Concentrations and circulating molecular forms in bovine plasma. J. Immunoassay 11:177-198.

Kirkpatrick, B. D., F. Noel, P. D. Rouzier, J. L. Powell, J. W. Pape, G. Bois, W. K. Alston, C. J. Larsson, K. Tenney, C. Ventrone, C. Powden, M. Sreenivasan, and C. L. Sears. 2006. Childhood cryptosporidiosis is associated with a persistent systemic inflammatory response. Clin. Infect. Dis. 43:604-608.

Klein, P., T. Kleinová, Z. Volek, and J. Simůnek. 2008. Effect of Cryptosporidium parvum infection on the absorptive capacity and para- 
cellular permeability of the small intestine in neonatal calves. Vet. Parasitol. 152:53-59.

Koepke, J., D. Lim, P. Wales, P. Wizzard, D. Sigalet, J. Li, J. Turner, and C. Levesque. 2015. Glucagon-like peptide 2 and epidermal growth factor promote intestinal adaptation in two neonatal intestinal failure models. FASEB J. 29:265.1.

Lacroix, S., R. Mancassola, M. Naciri, and F. Laurent. 2001. Cryptosporidium parvum-specific mucosal immune response in C57BL/6 neonatal and gamma interferon-deficient mice: Role of tumor necrosis factor alpha in protection. Infect. Immun. 69:1635-1642.

Liu, J., S. Enomoto, C. A. Lancto, M. s. Abrahamsen, and M. S. Rutherford. 2008. Inhibition of apoptosis in Cryptosporidium parvuminfected intestinal epithelial cells is dependent on survivin. Infect. Immun. 76:3784-3792.

Lorenz, I., J. Fagan, and S. J. More. 2011. Calf health from birth to weaning. II. Management of diarrhoea in pre-weaned calves. Ir. Vet. J. 64:9.

Malmuthuge, N., M. Li, L. A. Goonewardene, M. Oba, and L. L. Guan. 2013. Effect of calf starter feeding on gut microbial diversity and expression of genes involved in host immune responses and tight junctions in dairy calves during weaning transition. J. Dairy Sci. 96:3189-3200.

Mariano, C., H. Sasakib, D. Brites, and M. A. Britoa. 2011. A look at tricellulin and its role in tight junction formation and maintenance. Eur. J. Cell Biol. 90:787-796.

McAllister, T. A., M. E. Olson, A. Fletch, M. Wetzstein, and T. Entz. 2005. Prevalence of Giardia and Cryptosporidium in beef cows in southern Ontario and in beef calves in southern British Columbia. Can. Vet. J. 46:47-55.

McDonald, V., R. C. G. Pollock, W. Dhaliwal, S. Naik, M. J. G. Farthing, and M. Bajaj-Elliott. 2006. A potential role for interleukin-18 in inhibition of the development of Cryptosporidium parvum. Clin. Exp. Immunol. 145:555-562.

Mookherjee, N., H. H. Wilson, S. Doria, Y. Popowych, R. Falsafi, J. J. Yu, Y. Li, S. Veatch, F. M. Roche, K. L. Brown, F. S. Brinkman, K. Hokamp, A. Potter, L. A. Babiuk, P. J. Griebel, and R. E. Hancock. 2006. Bovine and human cathelicidin cationic host defense peptides similarly suppress transcriptional responses to bacterial lipopolysaccharide. J. Leukoc. Biol. 80:1563-1574.

Moran, A. W., M. Al-Rammahi, C. Zhang, D. Bravo, S. Calsamiglia, and S. P. Shirazi-Beechey. 2014. Sweet taste receptor expression in ruminant intestine and its activation by artificial sweeteners to regulate glucose absorption. J. Dairy Sci. 97:4955-4972.

Moran, G. W., C. O'Neill, and J. T. McLaughlin. 2012. GLP-2 enhances barrier function and attenuates TNFo-induced changes in a Caco-2 cell model of the intestinal barrier. Regul. Pept. 178:95101.

Muñoz-Caro, T., M. Lendner, A. Daugschies, C. Hermosilla, and A. Taubert. 2015. NADPH oxidase, MPO, NE, ERK1/2, p38 MAPK and $\mathrm{Ca} 2+$ influx are essential for Cryptosporidium parvum-induced NET formation. Dev. Comp. Immunol. 52:245-254.

Neal, M. D., W. M. Richardson, C. P. Sodhi, A. M. Russo, and D. J. Hackam. 2011. Intestinal stem cells and their roles during mucosal injury and repair. J. Surg. Res. 167:1-8.

Robinson, P., P. C. Okhuysen, C. L. Chappell, D. E. Lewis, I. Shahab, A. Janecki, and A. C. White Jr. 2001. Expression of tumor necrosis factor alpha and interleukin $1 \beta$ in jejuna of volunteers after experimental challenge with Cryptosporidium parvum correlates with exposure but not with symptoms. Infect. Immun. 69:1172-1174.

Santín, M., J. M. Trout, L. Xiao, L. Zhou, E. Greiner, and R. Fayer. 2004. Prevalence and age-related variation of Cryptosporidium species and genotypes in dairy calves. Vet. Parasitol. 122:103-117.

Schurink, M., E. M. W. Kooi, C. V. Hulzebos, R. G. Kox, H. Groen, E. Heineman, A. F. Bos, and J. B. F. Hulscher. 2015. Intestinal fatty acid-binding protein as a diagnostic marker for complicated and uncomplicated necrotizing enterocolitis: a prospective cohort study. PLoS One 10:e121336. https://doi.org/10.1371/journal. pone. 0121336

Stroup, W. W. 2015. Rethinking the analysis of non-normal data in plant and soil science. Agron. J. 107:811-827.

Taylor-Edwards, C. C., D. G. Burrin, J. J. Holst, K. R. McCleod, and D. L. Harmon. 2011. Glucagon-like peptide-2 (GLP-2) increases small intestinal blood flow and mucosal growth in ruminating calves. J. Dairy Sci. 94:888-898.

Thompson, R. C. A., C. S. Palmer, and R. O'Handley. 2008. The public health and clinical significance of Giardia and Cryptosporidium in domestic animals. Vet. J. 177:18-25.

Tzipori, S., and H. Ward. 2002. Cryptosporidiosis: Biology, pathogenesis and disease. Microbes Infect. 4:1047-1058.

Walker, M. P., C. M. Evock-Clover, T. H. Elsasser, and E. E. Connor 2015. Short communication: Glucagon-like peptide-2 and coccidiosis alter tight junction gene expression in the gastrointestinal tract of dairy calves. J. Dairy Sci. 98:3432-3437.

Yang, Z., Y. Fu, P. Gong, J. Zheng, L. Liu, Y. Yu, J. Li, H. Li, J. Yang, and X. Zhang. 2015. Bovine TLR2 and TLR4 mediate Cryptosporidium parvum recognition in bovine intestinal epithelial cells. Microb. Pathog. 85:29-34.

Yu, C., G. Jia, Y. Jiang, Q. Deng, Z. Chen, Z. Xu, X. Chen, and K. Wang. 2014. Effect of glucagon-like peptide 2 on tight junction in jejunal epithelium of weaned pigs through MAPK signaling pathway. Asian-australas. J. Anim. Sci. 27:733-742.

Zambriski, J. A., D. V. Nydamb, Z. J. Wilcox, D. D. Bowman, H O. Mohammed, and J. L. Liotta. 2013. Cryptosporidium parvum: Determination of $\mathrm{ID}_{50}$ and the dose-response relationship in experimentally challenged dairy calves. Vet. Parasitol. 197:104-112. 